\title{
CAMA
}

Centre for Applied Macroeconomic Analysis

\section{Factors affecting renters' electricity use: more than split incentives}

\section{CAMA Working Paper 82/2020 September 2020}

Rohan Best

Department of Economics, Macquarie University

\section{Paul J. Burke}

Crawford School of Public Policy, ANU

Centre for Applied Macroeconomic Analysis, ANU

\section{Shuhei Nishitateno}

School of Policy Studies, Kwansei Gakuin University

\section{Abstract}

This paper uses data from the 2015 Residential Energy Consumption Survey to explore the extent to which renters' electricity use in the United States exceeds that of otherwise similar non-renters. Renting households are found to use approximately $9 \%$ more electricity than non-renters when controlling for location, socioeconomic, and many appliance-quantity controls. There are multiple factors that explain this extra electricity use, including inferior energy efficiency of appliances, behavioural factors, differences in bill payment responsibilities, and additional reliance by renters on electric space and water heaters. The paper finds that none of these factors are dominant. The phenomenon of renters' (conditionally) higher electricity use is thus best understood as one that emerges from multiple sources. 


\title{
Keywords
}

Split incentives, rent, electricity consumption, efficiency, household survey, United States

\author{
JEL Classification
}

Address for correspondence:

(E) cama.admin@anu.edu.au

ISSN 2206-0332

The Centre for Applied Macroeconomic Analysis in the Crawford School of Public Policy has been established to build strong links between professional macroeconomists. It provides a forum for quality macroeconomic research and discussion of policy issues between academia, government and the private sector.

The Crawford School of Public Policy is the Australian National University's public policy school, serving and influencing Australia, Asia and the Pacific through advanced policy research, graduate and executive education, and policy impact. 


\section{Factors affecting renters' electricity use: more than split incentives}

Rohan Best*, Paul J. Burke **, Shuhei Nishitateno ***

1 September 2020

This paper uses data from the 2015 Residential Energy Consumption Survey to explore the extent to which renters' electricity use in the United States exceeds that of otherwise similar non-renters. Renting households are found to use approximately $9 \%$ more electricity than non-renters when controlling for location, socioeconomic, and many appliance-quantity controls. There are multiple factors that explain this extra electricity use, including inferior energy efficiency of appliances, behavioural factors, differences in bill payment responsibilities, and additional reliance by renters on electric space and water heaters. The paper finds that none of these factors are dominant. The phenomenon of renters' (conditionally) higher electricity use is thus best understood as one that emerges from multiple sources.

Keywords: split incentives, rent, electricity consumption, efficiency, household survey, United States

* Corresponding author. Department of Economics, Macquarie University, NSW 2109, Australia. Email: rohan.best@mq.edu.au.

** Crawford School of Public Policy, Australian National University, ACT 2601, Australia.

*** School of Policy Studies, Kwansei Gakuin University, Hyogo 669-1337, Japan. 


\section{Introduction}

How much extra electricity do renters use relative to comparable non-renters, and what explains any difference? Multiple factors may be relevant. In cases where landlords pay the energy bill, renters do not face a price-based incentive to reduce electricity use. This is referred to as a "consumption split incentive".1 Landlords may also underinvest in energy efficiency due to information asymmetries, as is often likely to be the case for insulation given the difficulty of observing its quality and quantity. This is called an "efficiency split incentive".

Other explanations, such as possible behavioural channels and the use of substitute fuel types, have been less analysed. It is possible, for example, that renters display different average behaviours in terms of the number of hours spent watching television and using lighting. Renters may also be more reliant on some certain electrical appliances, such as space heaters, especially if there are barriers to the use of natural gas in the home.2

Understanding potential renter effects on electricity consumption is important for a number of reasons. Renters make up over 30\% of US households (Pew Research Center 2017) and tend to be more disadvantaged from a socioeconomic perspective. The 2015 Residential Energy Consumption Survey (RECS) indicates that over $30 \%$ of renting households had annual gross household incomes of less than $\$ 20,000$, compared to $10 \%$ of non-renters (US Energy Information Administration 2018a). Any factors that would place upward pressure on their electricity bills would contribute to financial stress. Inefficiently high electricity usage quantities would also contribute to increased emissions of carbon dioxide and other pollutants from the electricity sector. Steps that could help to improve energy efficiency would help to alleviate these issues, while also allowing for greater enjoyment of energy services.

Previous findings on the effects of renting on energy use and expenditure have been mixed, perhaps in part because the sets of control variables that have been used in the analyses are different. Melvin (2018) found that a split-incentive rental market failure has led to 3\% higher total energy consumption in the US, based on the 2009 Residential Energy Consumption Survey. Rehdanz (2007) found lower expenditures on space heating and hot water supply for owner-occupiers in Germany. Some studies have found an effect in the opposite direction for other developed countries, with Wood et al. (2012) for example finding that energy expenditure by private renters in Australia is lower than that for homeowners. For the United Kingdom, Meier and Rehdanz (2010) found a positive effect of home ownership in explaining heating expenditure per room.

A number of prior studies focus on specific split-incentive effects that could raise energy consumption. For example, Levinson and Niemann (2004) investigated consumption split incentives and found that the amount of extra rent for households who do not pay their energy bill is less than the cost of the energy used. Making renters responsible for energy bills is thought to potentially reduce energy consumption by around 25\% (Elinder et al. 2017; Brewer 2018). Principal-agent problems affecting residential energy efficiency have also

\footnotetext{
1 While consumption split incentives are primarily an issue affecting renters, approximately $2 \%$ of owner-occupiers also do not pay their full electricity bill (Gillingham et al. 2012; US Energy Information Administration 2018a).

2 Landlords may prefer to avoid natural gas connections due to the additional fees involved, and because they are also sometimes responsible for paying natural gas usage charges. The survey data indicate that landlords pay at least part of the natural gas bill for up to $26 \%$ of the group of renting households who have a natural gas connection (US Energy Information Administration 2018a).
} 
been extensively considered (Gillingham et al. 2012; Myers 2013; Houde and Spurlock 2016; Joskow 2016).

There are many economic and social factors that are relevant for residential energy consumption. Jones and Lomas (2015) investigated socioeconomic determinants of high electricity consumption in the United Kingdom, finding that income is a key factor but education is not. Age of the survey respondent is another potentially important determinant, with younger respondents tending to report higher household electricity consumption in China, other things equal (Chen et al. 2013). It is also important to control for affluence given its negative correlation with renting. This can be done either directly or in an indirect way by controlling for variables that reflect resource differences across households, such as income, education, age, property size, and household contents.

This paper has two objectives. First, it aims to quantify the magnitude of the effect of renting on electricity consumption after conditioning for a larger set of covariates than prior studies. The sequential addition of control variables will provide information on how conclusions about the renter effect rely on the controls that are included. Second, the paper seeks to examine the possible channels through which renter effects may occur.

A key finding is that a negative unconditional effect of renting on electricity use turns into a positive conditional effect when suitable controls are added. Renters use 6\% more electricity than non-renters on average, after controlling for basic socioeconomic factors. This increases to around 9\% when controlling for quantities of appliances that are less popular in rented households on average. The paper then considers the various channels for this type of effect, including split incentives and behavioural differences. Finally, the paper quantifies the effect of renting on uptake of appliances. The findings suggest that renters are more likely to have electric space and water heaters and that there is evidence of some relevant behavioural differences. For example, renters are more likely to have the main television on for at least four hours on a weekday, all else equal.

\section{Data}

The data are from the 2015 Residential Energy Consumption Survey (RECS) of the US Energy Information Administration (2018a). This is a nationally representative survey of 5,686 US households. Data collection in the RECS in 2015 was carried out through a combination of computer-assisted personal interviews and self-administered reporting. It asked many questions about energy use over the prior year. In the current paper, households for whom electricity use is imputed will be excluded from the electricity use regressions. 3 The survey covers single-family homes, units, and mobile homes. Group quarters such as prisons, military barracks, and nursing homes are excluded. Probability weights are available, so each surveyed household can potentially be weighted according to how many households in the US population it represents. These weights are used in weighted least squares regressions (see robustness tests available through the online code).

The survey data provide evidence of substantial differences between renting and non-renting households. Electricity consumption is $35 \%$ lower for renter households on average, as evident in Table A.1. However, it is important to consider key factors that could explain this difference, as is done in the econometric analysis. Renter households on average have lower

3 The US EIA impute data in cases such as when households provide responses that are not internally consistent or when data are unavailable, such as in cases where households are not separately billed for energy use. Robustness results are similar for the full sample of 5,686 (see online code). 
income, live in smaller homes, and are more likely to have recently occupied their residence (i.e. moved in within the last five years).

Figure 1 reveals the link between income and electricity consumption. For non-renters, higher income tends to be associated with higher electricity consumption. This relationship is less clear for renters. $86 \%$ of renters are in the bottom four income bands shown in the Figure, meaning that only a small share of renting households had annual gross household incomes above $\$ 80,000$ as of 2015 . Only $62 \%$ of non-renters are in the bottom four income bands.
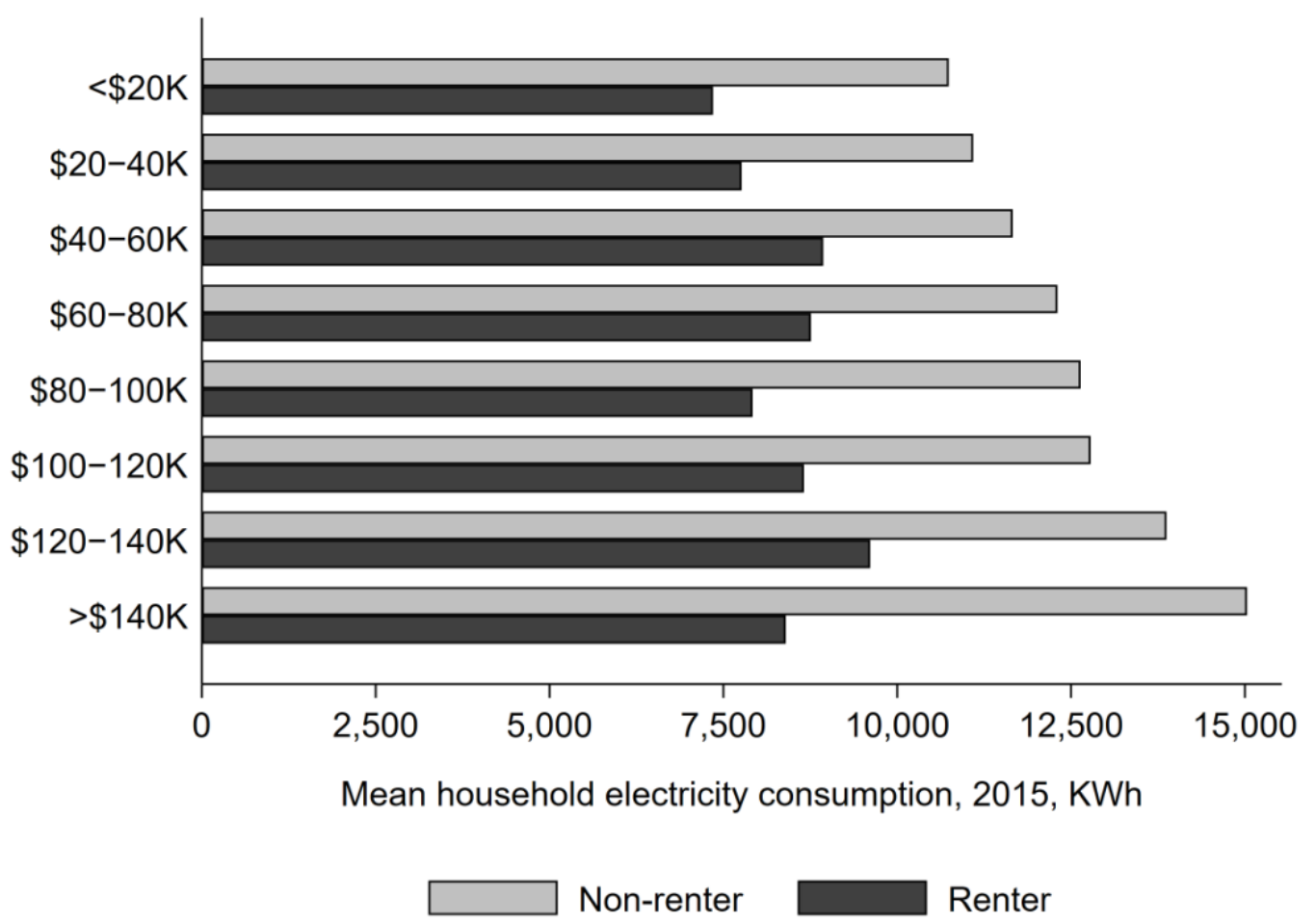

Figure 1. Mean household electricity consumption in 2015, kilowatt hours, by income category. This includes imputed electricity consumption for 620 of 5,686 households. A similar figure is available through the online code that excludes imputed values. Source: US Energy Information Administration (2018a).

Renters also differ in terms of the quantity of appliances in their household. Renters generally have less electrical equipment: only $83 \%$ of renters have air conditioning of some type (compared to $89 \%$ of non-renters), while only $48 \%$ of renters have electrical clothes dryers (compared to $75 \%$ of non-renters). 4 Exceptions include that renters are more likely to use electricity for some key purposes such as space heating, water heating, and cooking - as evident in Table A.1. As many as $47 \%$ of renters have electric space heaters in the home, compared to only $30 \%$ of non-renters.

Natural gas, the main alternative residential energy source, is available in the neighbourhood for a larger percentage of renters than non-renters. However, renters are nevertheless less likely to use natural gas than non-renters (US Energy Information Administration 2018a). On some other dimensions, renters and non-renters are actually quite similar. For example, there

${ }_{4}$ Renters are more likely to have individual air conditioning units ( $32 \%$ for renters; $21 \%$ for nonrenters) but less likely to have central air conditioning ( $53 \%$ for renters; $73 \%$ for non-renters). $2 \%$ of renters have both central and individual air conditioning. $5 \%$ of non-renters also have both. 
are 2.6 people per household in non-renting households on average, compared to 2.5 for renting households (see Table A.1).

As can be seen in Figure 2, non-renters are more likely to have adequate insulation. Nonrenters also have higher uptake rates of every type of energy-star appliance shown in the Figure. For example, $87 \%$ of non-renting households have adequate insulation in the home, compared to $72 \%$ of renters. In relative terms, more than twice as many non-renting households have access to energy-star-rated equipment such as windows, dishwashers, and freezers.

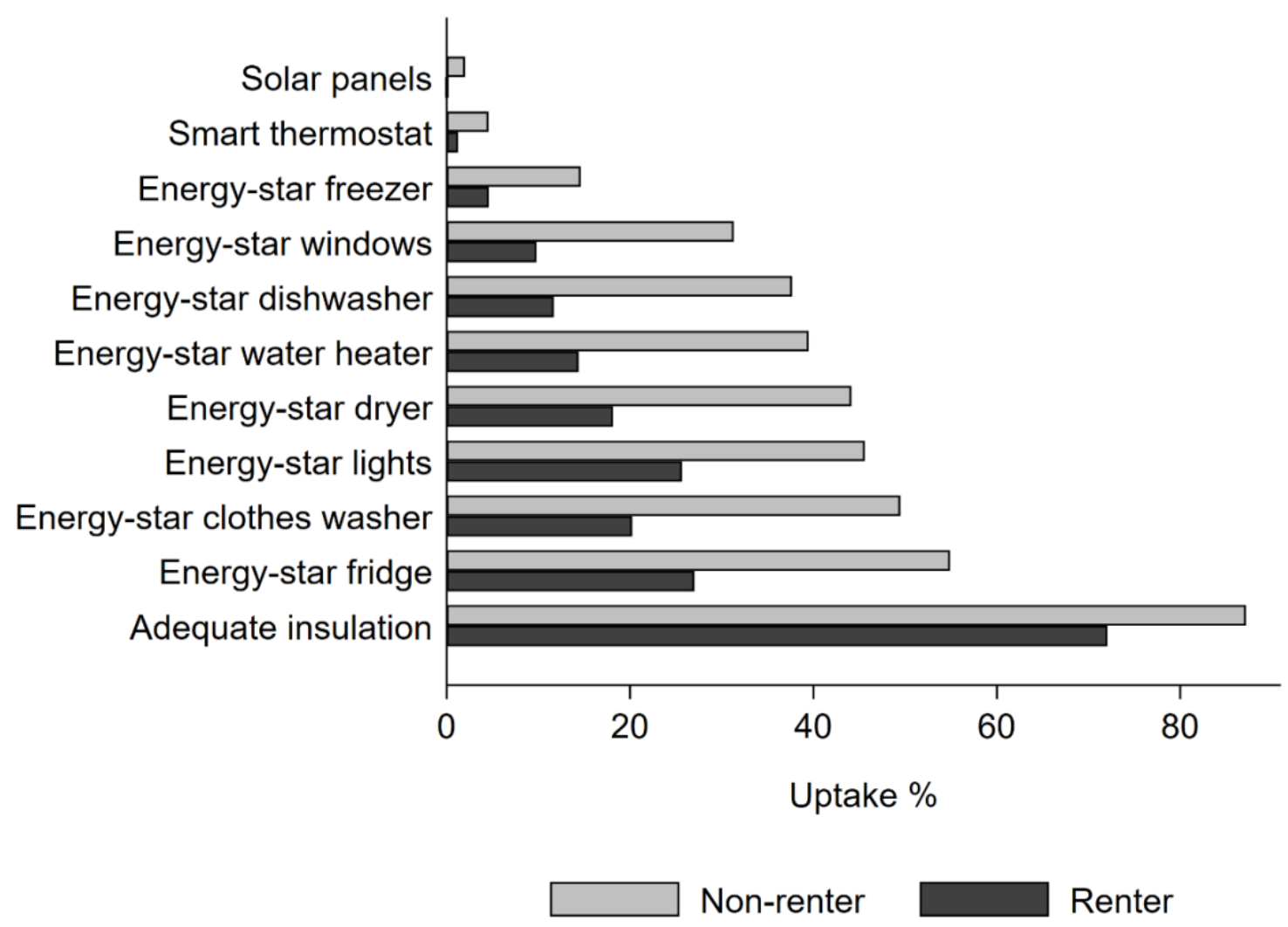

Figure 2. Proportion of households with each energy-efficient installation in 2015, by rental status. Source: US Energy Information Administration (2018a).

\section{Method}

\subsection{Electricity consumption model}

An initial regression model explaining household electricity consumption is given in equation (1).

$\ln E_{h}=\theta+\alpha R_{h}+\boldsymbol{L}_{h}^{\prime} \boldsymbol{\beta}+\boldsymbol{S}_{h}^{\prime} \boldsymbol{\gamma}+\boldsymbol{F}_{h}^{\prime} \boldsymbol{\delta}+\rho \ln P_{h}+\varepsilon_{h}$

The dependent variable is the $\log$ of electricity consumption by household $h, \ln E_{h}$. The key explanatory variable is $R$, a binary variable equal to one for renting households and zero for non-renters.

$L$ is a vector of location variables, including binary variables for metropolitan status, neighbourhoods that have natural gas, and climate zones. There are 11 climate zones in the United States based on the International Energy Conservation Code (IECC) classification 
(Baechler et al. 2015). $S$ refers to socioeconomic and related characteristics. This includes series of binary variables for income and education categories, variables related to socioeconomic characteristics such as the physical size of houses in square feet (logged), along with the other variables listed in Appendix Table A.1.

$F$ is a vector of variables describing energy appliance quantities that are less prevalent among renting households. This includes most types of appliances and electrical equipment, including refrigerators, as is evident in Table A.1. As mentioned, the quantity of appliances is closely related to socioeconomic characteristics such as wealth, as higher-wealth households can afford more appliances.

$P$ is the average electricity price. This is total electricity expenditure divided by total electricity consumption for each household. This variable does not feature in many of the estimates in Section 4 due to possible endogeneity concerns, as the average price is itself a function of the quantity of use. However including the variable has only a minor empirical effect on the renter coefficient.

Standard errors will be robust to heteroscedasticity and clustered at the climate-zone level. This is reasonable as the data are from a survey with a sample design that was based on regional-level stratification and random selection of households within regions (US Energy Information Administration 2015). While the regions used for stratification are not coded into the dataset, climate zones provide a useful approximation. Robustness tests without clustering are available through the online code.

\subsection{Models for channels explaining renter effects on electricity}

How much of the renter effect on electricity consumption relates to various potential channels is then assessed by successively adding groups of variables. The extra groups of variables are shown in equation (2):

$\ln E_{h}=\theta+\alpha R_{h}+\boldsymbol{L}_{h}^{\prime} \boldsymbol{\beta}+\boldsymbol{S}_{h}^{\prime} \boldsymbol{\gamma}+\boldsymbol{F}_{h}^{\prime} \boldsymbol{\delta}+\rho \ln P_{h}+\boldsymbol{M}_{h}^{\prime} \boldsymbol{\lambda}+\boldsymbol{C}_{h}^{\prime} \boldsymbol{\mu}+\boldsymbol{V}_{h}^{\prime} \xi+\boldsymbol{B}_{h}^{\prime} \boldsymbol{\varphi}+\omega N_{h}+\varepsilon_{h}$

If the renter effect were to disappear upon the inclusion of a group of variables, this would provide evidence that these variables are key channels via which renting status is relevant for household electricity use. The analysis thus examines what happens to $\alpha$ upon the inclusion of the additional controls.

There are several appliance/equipment types, such as electrical space and water heaters, that are more common among renters. These are included in the $M$ vector. One reason for renters being more likely to have electrical heaters is that a smaller proportion of renters use natural gas, possibly due to being less likely to have a connection and to not wanting to use available natural gas heaters (which may not be energy efficient).5 Renters may also be familiar with use of portable space heaters on account of having moved more often and owning these appliances already. The $N$ variable equals one for households who do not use natural gas.

$C$ is a vector of energy efficiency variables. It includes binary variables for having an energystar-rated appliance. These cover eight categories of appliance for which energy-star appliance questions appeared in the survey.6 The energy-star program is a US governmentbacked program that gives a star symbol to energy-efficient appliances. For other energy-

\footnotetext{
5 The proportion of renters who do not use natural gas in the 2015 RECS is higher than that for nonrenters by three percentage points.

${ }_{6}$ Products are listed as being either energy-star certified or not, matching the binary nature of the variable.
} 
using devices, such as air conditioners and space heaters, variables that measure the age of the appliance are used in the econometric analysis as a proxy for efficiency. A reasonable assumption is that newer appliances are more efficient. The results in Section 5 also control for the number of each type of these appliances.

$V$ is a vector of variables related to behavioral factors, including the amount of time spent using the main television and using lighting. There is also a binary variable equal to one for households who pay their full electricity bill, as opposed to sharing the bill with landlords or others. This is recorded in the $B$ vector, with a similar variable being included for natural gas. Other variables are listed in Table A.1.

A cross-sectional approach is appropriate for this paper given that the "between variation" across households is of a higher level of interest than "within variation" exhibited by households that switch between renting and not renting. Only a minority of households make such a switch in any year. The real interest lies in comparing the underlying cross-sectional differences between renters and non-renters.

\subsection{Theoretical expectations of coefficient signs}

Theory can guide expectations for the coefficient signs. For example, households having higher incomes are likely to use more electricity, based on a positive income elasticity of demand if electricity is a normal good. Larger houses and more electrical appliances are likely to mean more in the way of electricity consumption. Having energy-star windows likely leads to lower electricity consumption for heating and cooling compared to households who have less efficient windows. Increased use of electrical appliances is expected to be associated with greater electricity consumption. Higher prices should be associated with lower consumption levels, based on a downward-sloping demand curve for electricity.

\subsection{Explaining behaviour and appliance uptake}

The analysis then turns to further investigation of the individual channels through which there could be renter effects on household electricity use. Equation (3) uses a logit model to do so:

$\ln \left[p^{j} /\left(1-p^{j}\right)\right]=\theta+\alpha^{j} R_{h}+\boldsymbol{L}^{\prime}{ }_{h} \boldsymbol{\beta}^{j}+\boldsymbol{S}_{h}{ }_{h} \boldsymbol{\gamma}^{j}+\varepsilon_{h}^{j}$

The dependent variable is the log of the odds of each of a number of binary outcome variables. The odds are the probability $(p)$ divided by the complement $(1-p)$. Odds ratios will be displayed in the regression output tables; these are found by taking the natural exponent of coefficients in equation (3). 7 The $j$ superscript denotes that separate regressions will be run for various dependent variables. The examined binary variables include the presence of an adequate level of insulation, energy-star rated appliances, and key behavioural variables. An ordinary least squares model will also be used for numerical dependent variables.

\subsection{Econometric challenges}

Omitted variable bias is a potential concern given that it is challenging to include all relevant determinants of residential energy-use outcomes. However the analysis uses a long list of included variables, as shown in Table A.1. Location binary variables help to control for unobserved heterogeneity at the regional level, including metropolitan status and climatezone variables. Some relatively high $R$-squared values are obtained, indicating that quite large shares of the variation in the dependent variables can been explained.

7 Results using a linear probability model will also be shown. 
A comprehensive wealth variable is not available. This issue is addressed through including variables related to wealth, including income, the survey respondent's education level, and respondent age. House size is also related to wealth, so controlling for the log residential area in square feet, in addition to the numbers of rooms and of bathrooms, is also useful. A vector of appliance quantities is also a key set of controls. Preferences regarding energy conservation could be another omitted variable, although the models do include various behavioural controls.

Multicollinearity could be an issue if there are high correlations among the explanatory variables. Indeed Huebner et al. (2016) identified multicollinearity as an important issue when analysing factors affecting residential electricity use. This paper takes the approach of progressively adding variables in successive regressions and ensuring that the variance inflation factor remains at a reasonable level.

Reverse causation could be an issue if electricity use has a causal effect on subsequent purchases of appliances. For example, high electricity consumption and expenditure may lead to subsequent purchases of energy-efficient appliances. But this is not likely to pose a major problem, as the survey variables are generally contemporaneous. Households may have earlier purchased some energy-efficient appliances in response to past high electricity use. Or they may purchase energy-efficient appliances in the future as a result of current high electricity use. The number of cases for which high electricity use in the survey year (2015) influenced appliance purchase in the same year is likely to be small.

More proactive approaches to addressing potential reverse causation are also pursued. Effects are assessed both with and without the energy appliance controls. Robustness results that drop households who made purchases of major equipment in the previous two years provide further confidence in the results. 8

There may also be measurement error or imprecision in variable measurement. For example some households may respond incorrectly to questions about issues such as the type of energy used for applications such as water heating. 9 Respondents may also not know if appliances are energy-star certified. While $90 \%$ of American households recognize the energy-star symbol (United States Environmental Protection Agency 2018), some appliances have had their labels removed, and residents may not pay attention to each label. However there are similar results in the online code when controlling for binary variables for households who did not know if they had energy-star appliances.

\section{Results: electricity consumption}

Table 1 shows a negative and significant renter coefficient in column (1), without controls, in explaining log electricity consumption. Being a renter is associated with electricity consumption on average being 37\% lower compared to other households. 10 This is consistent with Figure 1, which showed a negative unconditional relationship between renting and electricity consumption. The negative and significant renter coefficient is similar in column (2) when controlling for location variables. However the coefficient may be due to simple

\footnotetext{
8 This includes purchases of fridges, freezers, dryers, space heating, central air conditioning, individual air conditioning, and water heating.

9 The Energy Information Administration (EIA) conducted quality checks such as reviewing patterns in consumption data, comparing this to energy use responses by households, and correcting contradictions (US Energy Information Administration 2018b). However these would not have excluded all sources of measurement error.
} $10 \exp (-0.467)-1=-0.37$. 
reasons such as rented dwellings being smaller. When controlling for the size of the dwelling and the type of housing (such as mobile homes, separate houses, and apartments) in column (3), the renter effect becomes positive in point estimate terms and statistically indistinguishable from zero.

Table 1. Results, dependent variable: $\log$ annual electricity consumption (kWh per annum).

\begin{tabular}{lllllll}
\hline & $(1)$ & $(2)$ & $(3)$ & $(4)$ & $(5)$ & $(6)$ \\
\hline Renter coefficient & $-0.467 * * *$ & $-0.407^{* * *}$ & 0.028 & $0.057 * * *$ & $0.093^{* * *}$ & $0.077 * *$ \\
Standard error & $(0.042)$ & $(0.029)$ & $(0.028)$ & $(0.018)$ & $(0.014)$ & $(0.026)$ \\
Controls: & & & & & & \\
Location & No & Yes & Yes & Yes & Yes & Yes \\
House size and type & No & No & Yes & Yes & Yes & Yes \\
Socioeconomic & No & No & No & Yes & Yes & Yes \\
Appliance \#: less for renters & No & No & No & No & Yes & Yes \\
Log electricity price & No & No & No & No & No & Yes \\
$R 2$ & 0.096 & 0.287 & 0.407 & 0.499 & 0.567 & 0.623 \\
\hline
\end{tabular}

Notes. $* * *, * *, *$ show statistical significance at 1,5 and 10 per cent level respectively. Each column uses 5,066 observations. Robust standard errors are clustered by region (climate zone). The comprehensive lists of controls are given in Tables A.1 and A.2.

Column (4) of Table 1 includes the full set of socioeconomic controls, as listed in Table A.1. Once these variables are controlled for, renters are found to consume more electricity than non-renters, with statistical significance at the $1 \%$ level. There is a positive and significant renter effect of approximately $6 \%$ in column (4) when the full set of socioeconomic variables are included as controls. When also controlling for appliance quantities that renters have fewer of (see Appendix Table A.1), renters are found to use approximately $9 \%$ more electricity on average, as in column (5). This magnitude falls to approximately $8 \%$ when controlling for the log electricity price in column (6).

\section{Results: channels of a renter effect}

\subsection{Channels of effects on electricity consumption}

Table 2 seeks to investigate the channels through which the renter effect on residential electricity consumption occurs. It does so by adding groups of control variables, one at a time, and then examining their influence on the coefficient for the renter variable.

Column (1) is the reference case, with a renter coefficient of 0.077 when controls for location, socioeconomic variables, quantities for appliances that renters have fewer of, and the $\log$ electricity price are included. The renter coefficient is reduced to 0.046 in column (2) when also controlling for quantities of appliances that renters have more of, such as electrical space heaters and individual air conditioning units. The results suggest that a substantial proportion of the renter effect is related to renters having more individual air conditioning units and being more likely to use electricity for activities such as space heating, water heating, and cooking (all else equal). If electricity is being used in this way, natural gas use would likely be lower. Higher expenditure on electricity may thus be partially offset by lower bills for natural gas.11

Column (3) of Table 2 includes appliance efficiency controls such as binary variables for households who have various energy-star appliances. The renter coefficient reduces to 0.067 , although this is only slightly lower than the reference case in column (1). These results thus

11 A regression in the online code finds that the number of individual air conditioning units has a positive and significant effect on log total expenditure on energy (electricity, natural gas, propane, and fuel oil/kerosene). This is not the case for electrical space and water heaters. 
do not suggest that an efficiency split incentive is the major contributor to energy use differences between renters and non-renters. Column (4) controls for behaviour related to electricity use. The renter coefficient is again 0.067. Similar results are obtained in columns (5) and (6) when controlling for a binary natural gas usage variable and for bill payment responsibility.

Column (7) of Table 2 controls for all of the channels simultaneously.12 The renter coefficient falls to closer to zero and is no longer statistically significant. This suggests that policy to address a single channel may be insufficient to address the issue of higher conditional electricity use by renters. Instead, multiple channels are relevant.

Table 2. Results, dependent variable: log annual electricity consumption (kWh per annum).

\begin{tabular}{llllllll}
\hline & $(1)$ & $(2)$ & $(3)$ & $(4)$ & $(5)$ & $(6)$ & $(7)$ \\
\hline Renter coefficient & $0.077^{*}$ & $0.046^{*}$ & $0.067 * *$ & $0.067 * *$ & $0.067^{* *}$ & $0.067 * *$ & 0.030 \\
Standard error & $(0.026)$ & $(0.023)$ & $(0.027)$ & $(0.023)$ & $(0.025)$ & $(0.026)$ & $(0.020)$ \\
$\begin{array}{l}\text { Controls: } \\
\text { Location }\end{array}$ & Yes & Yes & Yes & Yes & Yes & Yes & Yes \\
Socioeconomic & Yes & Yes & Yes & Yes & Yes & Yes & Yes \\
Appliance \#: less for renters & Yes & Yes & Yes & Yes & Yes & Yes & Yes \\
Log electricity price & Yes & Yes & Yes & Yes & Yes & Yes & Yes \\
Channels: & & & & & & & No \\
Appliance \#: more for renters & No & Yes & No & No & No & No & Yes \\
Appliance efficiency & No & No & Yes & No & No & No & Yes \\
Household behaviour & No & No & No & Yes & No & No & Yes \\
Binary natural gas variable & No & No & No & No & Yes & No & Yes \\
Bill payment responsibility & No & No & No & No & No & Yes & Yes \\
$R 2$ & 0.623 & 0.655 & 0.628 & 0.631 & 0.640 & 0.634 & 0.667 \\
\hline
\end{tabular}

Notes. ***,**, * show statistical significance at 1, 5 and 10 per cent level respectively. Each column uses 5,066 observations. Robust standard errors are clustered by region (climate zone). The comprehensive lists of controls are given in Tables A.1 and A.2. These tables also show the composition of each group of controls. For example, adequate insulation is included in the appliance efficiency category. Results are similar if the full sample of 5,686 is used or if the sample is restricted to the 5,358 households who pay their full electricity bill.

The socioeconomic controls include house size and type, which are related to wealth.

Table A. 2 shows the coefficients for the full set of control variables. There are numerous significant results for the socioeconomic variables. Being a higher-income household tends to be associated with higher electricity consumption. Households for which the respondent has completed high school but has not completed higher education do not have significantly different electricity consumption, although there is evidence that some college education is sufficient to help reduce electricity consumption. The effect of education in reducing electricity consumption is most pronounced for households with respondents who have completed a college bachelor degree or higher. Households with more people also on average use more electricity, as expected. Having more children under the age of 18 leads to lower electricity consumption (after controlling for the total number of people in the household).

Physical characteristics of dwellings are also relevant. Larger houses in terms of their floor area use more electricity, as expected (Table A.2). Attached dwellings use less electricity than mobile homes, all else equal. Houses that were built more recently also use less electricity, which may well be due to superior energy efficiency relative to older homes.

12 The renter coefficient is even closer to zero when using an expanded sample that includes households for whom electricity use is imputed. This is shown in a robustness test available through the online code. 
The Table A.2 estimates quantify the effect of many other variables. Having more electrical appliances leads to higher electricity consumption, as expected. There are positive effects of having more windows on log electricity consumption. Having air conditioning leads to around 13\% more electricity consumption (Table A.2) compared to not having air conditioning. The results may be underestimates of the effects of some energy appliance quantities due to the possibility that reverse causation is having small effects in the opposite direction.

Three of the energy-star variables produce negative and significant coefficients, showing the beneficial effect of efficiency on lower electricity use. Energy-star windows, for example, help to reduce electricity consumption by around $4 \%$. There are also negative and significant coefficients for energy-star freezers and light bulbs. The coefficient for the adequate insulation variable is negative but not statistically significant.

There is a negative and significant coefficient for the log of the average electricity price in Table A.2, with a magnitude of -0.55 . This can be interpreted as an estimate of the price elasticity of electricity demand. While there could be a risk of reverse causation from electricity quantity to electricity price, the estimate is within the range of results from earlier studies. For example, it is within the range of the short-run and long-run estimates of Burke and Abayasekara (2018), who used an instrumental variable approach.

A number of robustness tests, available through the online code, support the main results. This includes a test that excludes households who have made major new electrical equipment purchases in the previous two years.13 Results remain quite similar. Similar results are also obtained using probability weights, and the significance levels are mostly similar when not clustering standard errors by climate zone. Standard errors are also similar when estimated using bootstrapping. Relatively low variance inflation factors suggest that multicollinearity is not a major concern.

\subsection{Appliance uptake and behaviour}

Table 3 shows renter coefficients for regressions using binary measures of having key electrical appliances such as space heaters. The odds ratios for the renter variable are above one and significantly different to one, indicating that renters are more likely to have electric space and water heaters and electric cooking appliances, all else equal. There are also positive effects when estimating a linear probability model. These associations are consistent with the large impact on the renter coefficient in column (2) of Table 2 when these appliance types are controlled for.

Table 4 considers the extent to which rental status is a contributor to uptake of energyefficient appliances. Renters are found to have fewer energy-efficient appliances, holding the location and socioeconomic variables constant, as indicated by odds ratios of less than one. There is significance at the $1 \%$ level for the renter coefficient in relation to each of the odds ratios. The results in Table 4 are similar when also controlling for appliance quantities or when restricting the samples to households with particular appliances (e.g. restricting the dishwasher regression to households who have a dishwasher; see the online code).

13 This includes fridges, freezers, dryers, space heating, central air conditioning, individual air conditioning, and water heating. 
Table 3. Results for electrical equipment more commonly used by renters, 2015.

\begin{tabular}{|c|c|c|c|c|}
\hline Dependent variable & $\begin{array}{r}\text { Renter } \\
\text { coefficient: } \\
\text { odds ratio }\end{array}$ & $\begin{array}{r}\text { Standard } \\
\text { error }\end{array}$ & $\begin{array}{r}\text { Renter } \\
\text { coefficient } \\
\text { from linear } \\
\text { probability } \\
\text { model }\end{array}$ & $\begin{array}{r}\text { Standard } \\
\text { error }\end{array}$ \\
\hline Space heating (main fuel is electricity), binary & $1.847 * * *$ & $(0.160)$ & $0.095 * * *$ & $(0.016)$ \\
\hline Water heating (main fuel is electricity), binary & $1.545^{* * *}$ & $(0.164)$ & $0.067 * * *$ & $(0.017)$ \\
\hline Electrical cooking equipment, binary & $1.624 * *$ & $(0.343)$ & $0.088 * *$ & $(0.039)$ \\
\hline
\end{tabular}

Notes. $* * * * *, *$ show statistical significance at 1,5 and 10 per cent level respectively. Control variables (not shown) include location and socioeconomic controls. Only coefficients for the binary renter variable are shown. There are 5,686 observations. Standard errors are clustered by region (climate zone).

There appear to be greater constraints for immovable or less mobile upgrades, as expected. The odds ratios for insulation and energy-star windows are some of the lower coefficients in Table 4, indicating that renters are much less likely to have these housing features. More movable appliances, such as efficient freezers, are subject to lesser effects. This conclusion is supported by propensity score matching results in the online code, which find negative and significant effects of renting on the probability of having insulation or energy-star certified windows. The propensity score matching results do not indicate a significant effect of renting on the probability of having some of the more mobile energy-star items, including energy-star fridges, freezers, clothes washers, and dryers. 14

The linear probability model estimates in Table 4 show negative coefficients for the renter effect. The magnitudes suggest that renter access to energy-efficient items appears to be approximately 10 percentage points lower in most cases relative to non-renters. This is a larger effect than that estimated in the study by Davis (2012), which was based on the earlier 2005 Residential Energy Consumption survey, but smaller than the finding of Krishnamurthy and Kriström (2015), who used a sample of 11 OECD countries. There are relatively similar results in a study by Souza (2018) that uses a different dataset for the US.15 For example, the renter coefficient of -0.12 in the dishwasher regression in Table 4 is similar to a corresponding coefficient of -0.15 in the study by Souza (2018). A drawback of a linear probability model is that the errors will not be normally distributed, impeding the use of standard significance tests.

There are also numerous other factors that affect ownership of energy-efficient equipment (see results through the online code). There are positive effects of income on uptake of most energy-star appliances, although not insulation. There is also a positive effect of some college education on uptake of seven out of the eight energy-star appliances (relative to the excluded category of less than high school education). Newer houses are more likely to have adequate insulation or energy-star dishwashers.

14 This may be because renters can supply their own appliances if landlords do not supply particular appliances. While representative data are difficult to find, media reports often estimate that around $50 \%$ of rented apartments in Los Angeles do not have a fridge that has been supplied by the landlord (Trachta 2014).

15 The American Housing Survey is for a larger sample of households but provides less detail. 
Table 4. Odds ratios and linear probability model coefficients for energy efficiency.

\begin{tabular}{|c|c|c|c|c|}
\hline Dependent variable (binary) & $\begin{array}{r}\text { Renter } \\
\text { coefficient: } \\
\text { odds ratio }\end{array}$ & $\begin{array}{r}\text { Standard } \\
\text { error }\end{array}$ & $\begin{array}{r}\text { Renter } \\
\text { coefficient: } \\
\text { linear } \\
\text { probability } \\
\text { model }\end{array}$ & $\begin{array}{r}\text { Standard } \\
\text { error }\end{array}$ \\
\hline Adequate level of insulation & $0.415 * * *$ & $(0.037)$ & $-0.137 * * *$ & $(0.016)$ \\
\hline Energy-star qualified lightbulbs & $0.579 * * *$ & $(0.053)$ & $-0.118 * * *$ & $(0.021)$ \\
\hline Energy-star qualified windows & $0.433 * * *$ & $(0.074)$ & $-0.114 * * *$ & $(0.020)$ \\
\hline Energy-star qualified water heating & $0.528 * * *$ & $(0.058)$ & $-0.113 * * *$ & $(0.019)$ \\
\hline Energy-star qualified dishwasher & $0.417 * * *$ & $(0.038)$ & $-0.123 * * *$ & $(0.013)$ \\
\hline Energy-star qualified clothes washer & $0.620 * * *$ & $(0.057)$ & $-0.093 * * *$ & $(0.018)$ \\
\hline Energy-star qualified clothes dryer & $0.624 * * *$ & $(0.058)$ & $-0.087 * * *$ & $(0.017)$ \\
\hline Energy-star qualified refrigerator & $0.455^{* * *}$ & $(0.030)$ & $-0.175 * * *$ & $(0.013)$ \\
\hline Energy-star qualified freezer & $0.769 * * *$ & $(0.075)$ & $-0.018 * *$ & $(0.008)$ \\
\hline
\end{tabular}

Notes. $* * *, * *, *$ show statistical significance at 1,5 and 10 per cent level respectively. Control variables include location and socioeconomic controls. Only coefficients for the binary renter variable are shown. There are 5,686 observations. Standard errors are clustered by region (climate zone).

Table 5 estimates the effect of renting on some variables that might have a particularly large effect on household behaviour, such as having solar panels. The odds ratio for the renter coefficient in a logit regression for solar uptake is significant at the $10 \%$ level. The magnitude is well below one, suggesting that renters are much less likely to have solar panels. This is based on a smaller sample given that solar panel uptake was very low in some regions of the US in 2015 (which meant that there was no variation in some binary explanatory variables for households with solar panels). Renters are also less likely to have a smart thermostat and to be responsible for paying the full electricity bill, all else equal.

Table 5. Results for behavioural variables, renter coefficients, 2015.

\begin{tabular}{|c|c|c|}
\hline Dependent variable & $\begin{array}{r}\text { Renter } \\
\text { coefficient }\end{array}$ & $\begin{array}{r}\text { Renter } \\
\text { standard error }\end{array}$ \\
\hline \multicolumn{3}{|c|}{ Binary dependent variables, odds ratios shown for renter coefficient } \\
\hline On-site electricity generation from solar, binary & $0.126^{*}$ & $(0.146)$ \\
\hline Smart thermostat, binary & $0.267 * * *$ & $(0.060)$ \\
\hline Household pays for all electricity used, binary & $0.411 * * *$ & $(0.086)$ \\
\hline Most used TV on 4 plus hours a weekday, binary & $1.344 * * *$ & $(0.088)$ \\
\hline \multicolumn{3}{|c|}{ Integer dependent variables, OLS renter coefficients shown } \\
\hline Number of lights on at least 4 hours a day & -0.034 & $(0.270)$ \\
\hline Frequency of clothes dryer use per week & 0.276 & $(0.228)$ \\
\hline
\end{tabular}

Table 5 also assesses the relationship between renting and a number of reported behaviors. The odds ratio for the renter variable in a logit regression for households having the mostused television on for at least four hours a day is above one, suggesting that renters are more likely to watch television for long durations, all else equal. There are insignificant associations for the number of lights on for at least four hours a day and the frequency of clothes dryer use. However, the renter coefficient in the regression for the frequency of clothes dryer use becomes significant at the 5\% level when controlling for the vector of appliance quantities, including a binary control for having an electrical dryer (see the online code). 


\section{Conclusion and policy implications}

This paper finds that renting households tend to use less electricity than non-renters on account of factors such as house size and type. Once such factors have been accounted for, renters consume more electricity than otherwise similar non-renters. The estimated magnitude of the renter effect on electricity use of around 9\% is larger than in key prior studies, with some finding negative or small positive effects (Wood et al. 2012; Melvin 2018, for example). The approach in this paper of progressively adding control variables and examining what happens to the renter coefficient is useful in understanding the scope for mixed results in the literature.

The paper also explores channels through which renter effects may occur. An energyefficiency constraint provides only a partial explanation. Many other factors appear to be relevant, including renters being more likely to use electric heaters and being more likely to watch their main television for extended periods. Differences in bill payment responsibility are among other factors that are relevant in explaining the positive renter coefficient.

This paper seeks to add to previous studies that have tended to focus on one or two of these channels. Bird and Hernández (2012) described financing approaches to overcome the energy-efficiency split-incentive problem for rental properties. Charlier (2015) suggested that mandatory minimum efficiency standards may be appropriate to overcome a split-incentive problem. Burfurd et al. (2012) warned that mandatory minimum standards would lower the number of properties available for lease in Australia. Hernández and Phillips (2015) concluded that weatherization alone is not sufficient and there are other issues to focus on for low-income households and renters, based on a study of New York City. Household-specific metering and bill payment responsibility are known to help to conserve electricity (Elinder et al. 2017; Brewer 2018).

The results may be able to help policymakers to have a better understanding of how much of the renter effect relates to market failures and how much does not. Efficiency split incentives relate to information asymmetry and a market failure, while behavioral differences such as duration of television watching do not (Gillingham and Palmer 2014).

There is scope for governments to seek to address market failures affecting residential electricity use, including potentially through targeted tax credits for efficient appliances and equipment installed in rental properties, although detailed cost-benefit analyses would be useful before proceeding with this type of approach (Allcott and Greenstone 2012; Gillingham et al. 2018). Policymakers could also seek to take steps that help to place downward pressure on the overall share of households who do not pay their own electricity bill in order to reduce this split incentive. This is also a highly relevant issue given that timeof-use electricity prices are becoming increasingly important for managing the electricity grid. It is important that any policy plans are developed in a context-specific way and keep equity issues in mind.

The results in this paper, along with prior studies (Gandhi et al. 2016), reinforce the importance of considering behavioural factors. More precise information for households on the electricity requirements of individual appliances would be useful, as in many cases this is not clear. There is also scope for more research into the specific details of policy options for improving various residential energy use outcomes (Gillingham and Tsvetanov 2018; Myers and Souza 2019). 


\section{References}

Allcott, H., and M. Greenstone. (2012). "Is There an Energy Efficiency Gap?” Journal of Economic Perspectives 26 (1): 3-28.

Baechler, M.C., T.L. Gilbride, P.C. Cole, M.G. Hefty, and K. Ruiz. (2015). "HighPerformance Home Technologies: Guide to Determining Climate Regions by County." Pacific Northwest National Laboratory \& Oak Ridge National Laboratory 7 (August): $1-34$. https://www.energy.gov/sites/prod/files/2015/10/f27/ba_climate_region_guide_7.3.pdf.

Bird, S., and D. Hernández. (2012). "Policy Options for the Split Incentive: Increasing Energy Efficiency for Low-Income Renters." Energy Policy 48: 506-14. https://doi.org/10.1016/j.enpol.2012.05.053.

Brewer, D. (2018). "Equilibrium Sorting and Moral Hazard in Residential Energy Contracts" 2018. http://econ.msu.edu/seminars/docs/brewer_heekwon.pdf.

Burfurd, I., L. Gangadharan, and V. Nemes. (2012). "Stars and Standards: Energy Efficiency in Rental Markets." Journal of Environmental Economics and Management 64 (2): 15368. https://doi.org/10.1016/j.jeem.2012.05.002.

Burke, P.J., and A. Abayasekara. (2018). "The Price Elasticity of Electricity Demand in the United States: A Three-Dimensional Analysis.” Energy Journal 39 (2): 87-102. https://doi.org/10.5547/01956574.39.2.pbur.

Charlier, D. (2015). "Energy Efficiency Investments in the Context of Split Incentives among French Households." Energy Policy 87: 465-79. https://doi.org/10.1016/j.enpol.2015.09.005.

Chen, J., X. Wang, and K. Steemers. (2013). "A Statistical Analysis of a Residential Energy Consumption Survey Study in Hangzhou, China.” Energy and Buildings 66: 193-202. https://doi.org/10.1016/j.enbuild.2013.07.045.

Davis, L. (2012). "Evaluating the Slow Adoption of Energy Efficient Investments: Are Renters Less Likely to Have Energy Efficient Appliances?" NBER Conference Report In: The Design and Implementation of U.S. Climate Policy (September): 301-16. https://doi.org/10.3386/w16114.

Elinder, M., S. Escobar, and I. Petré. (2017). "Consequences of a Price Incentive on Free Riding and Electric Energy Consumption." Proceedings of the National Academy of Sciences of the United States of America 114 (12): 3091-96. https://doi.org/10.1073/pnas.1615290114.

Gandhi, R., C.R. Knittel, P. Pedro, and C. Wolfram. (2016). "Running Randomized Field Experiments for Energy Efficiency Programs: A Practitioner's Guide.” Economics of Energy and Environmental Policy 5 (2): 7-26. https://doi.org/10.5547/21605890.5.2.rgan.

Gillingham, K., M. Harding, and D. Rapson. (2012). "Split Incentives in Household Energy Consumption." The Energy Journal 33 (2): 37-62.

Gillingham, K., A. Keyes, and K. Palmer. (2018). "Advances in Evaluating Energy Efficiency Policies and Programs." Annual Review of Resource Economics 10 (1): 51132. https://doi.org/10.1146/annurev-resource-100517-023028. 
Gillingham, K., and K. Palmer. (2014). "Bridging the Energy Efficiency Gap: Policy Insights from Economic Theory and Empirical Evidence." Review of Environmental Economics and Policy 8 (1): 18-38. https://doi.org/10.1093/reep/ret021.

Gillingham, K., and T. Tsvetanov. (2018). "Nudging Energy Efficiency Audits: Evidence from a Field Experiment." Journal of Environmental Economics and Management 90: 303-16. https://doi.org/10.1016/j.jeem.2018.06.009.

Hernández, D., and D. Phillips. (2015). "Benefit or Burden? Perceptions of Energy Efficiency Efforts among Low-Income Housing Residents in New York City." Energy Research and Social Science 8: 52-59. https://doi.org/10.1016/j.erss.2015.04.010.

Houde, S., and C.A. Spurlock. (2016). "Minimum Energy Efficiency Standards for Appliances: Old and New Economic Rationales." Economics of Energy and Environmental Policy 5 (2): 65-83. https://doi.org/10.5547/2160-5890.5.2.shou.

Huebner, G., D. Shipworth, I. Hamilton, Z. Chalabi, and T. Oreszczyn. (2016). "Understanding Electricity Consumption: A Comparative Contribution of Building Factors, Socio-Demographics, Appliances, Behaviours and Attitudes." Applied Energy 177: 692-702. https://doi.org/10.1016/j.apenergy.2016.04.075.

Jones, R. V., and K.J. Lomas. (2015). "Determinants of High Electrical Energy Demand in UK Homes: Socio-Economic and Dwelling Characteristics." Energy and Buildings 101: 24-34. https://doi.org/10.1016/j.enbuild.2015.04.052.

Joskow, P.L. (2016). "Symposium on Energy Efficiency." Economics of Energy and Environmental Policy 5 (2): 1-6.

Krishnamurthy, C.K., and B. Kriström. (2015). "How Large Is the Owner-Renter Divide? Evidence from an OECD Cross-Section.” The Energy Journal 36 (4): 85-104. https://doi.org/10.2139/ssrn.2378890.

Levinson, A., and S. Niemann. (2004). "Energy Use by Apartment Tenants When Landlords Pay for Utilities." Resource and Energy Economics 26 (1): 51-75. https://doi.org/10.1016/S0928-7655(03)00047-2.

Meier, H., and K. Rehdanz. (2010). "Determinants of Residential Space Heating Expenditures in Great Britain.” Energy Economics 32 (5): 949-59. https://doi.org/10.1016/j.eneco.2009.11.008.

Melvin, J. (2018). "The Split Incentives Energy Efficiency Problem: Evidence of Underinvestment by Landlords.” Energy Policy 115 (February 2017): 342-52. https://doi.org/10.1016/j.enpol.2017.11.069.

Myers, E. (2013). "Asymmetric Information in Residential Rental Markets: Implications for the Energy Efficiency Gap." Energy Institute at Haas Working Paper 246, no. November. http://areweb.berkeley.edu/candidate/.

Myers, E., and M. Souza. (2019). "Social Comparison Nudges Without Monetary Incentives : Evidence from Home Energy Reports.” E2e Working Paper 041, no. March.

Rehdanz, K. (2007). "Determinants of Residential Space Heating Expenditures in Germany." Energy Economics 29: 167-82. https://doi.org/10.1016/j.eneco.2009.11.008.

Souza, M.N.M. (2018). "Why Are Rented Dwellings Less Energy-Efficient? Evidence from a Representative Sample of the U.S. Housing Stock.” Energy Policy 118 (March): 149- 
59. https://doi.org/10.1016/j.enpol.2018.03.013.

Trachta, A. (2014). "It's time to end L.A.'s sick game of refrigerator musical chairs." LA Weekly. https://www.laweekly.com/its-time-to-end-l-a-s-sick-game-of-refrigeratormusical-chairs/. Accessed 29 January 2020.

United States Environmental Protection Agency. (2018). “About Energy Star - 2017." https://www.energystar.gov/about. Accessed 31 July 2019.

US EIA (Energy Information Administration). (2015). “2015 RECS Technical Documentation," no. May. www.eia.gov.

US EIA (Energy Information Administration). (2018a). "Residential Energy Consumption Survey : 2015 RECS Survey Data." https://www.eia.gov/consumption/residential/data/2015/index.php?view=microdata.

US EIA (Energy Information Administration). (2018b). "Comparing the 2015 RECS with Previous RECS and Other Studies." https://www.eia.gov/consumption/residential/reports/2015/comparison/index.php.

Wood, G., R. Ong, and C. McMurray. (2012). "Housing Tenure, Energy Consumption and the Split-Incentive Issue in Australia." International Journal of Housing Policy 12 (4): 439-69. https://doi.org/10.1080/14616718.2012.730218. 
Table A.1. Descriptive statistics for households by renter status, 2015

\begin{tabular}{|c|c|c|c|c|c|c|c|}
\hline \multirow[b]{2}{*}{ Category } & \multirow[b]{2}{*}{ Variable } & \multicolumn{3}{|c|}{ Renter } & \multicolumn{3}{|c|}{ Non-renter } \\
\hline & & Min. & Mean & Max. & Min. & Mean & Max. \\
\hline Electricity & Electricity usage (2015), in kilowatt hours a & 59 & 7,997 & 37,478 & 742 & 12,318 & 63,217 \\
\hline \multirow[t]{3}{*}{ Location } & Metropolitan Statistical Area c & 1 & 1.16 & 3 & 1 & 1.26 & 3 \\
\hline & IECC Climate Code $_{c}$ & 1 & 5.47 & 11 & 1 & 5.58 & 11 \\
\hline & Neighbourhood availability of natural gas b & 0 & 0.73 & 1 & 0 & 0.68 & 1 \\
\hline \multirow{13}{*}{$\begin{array}{l}\text { Socio- } \\
\text { economic } \\
\text { (and related } \\
\text { variables) }\end{array}$} & Annual household income (prev. year) c & 1 & 2.64 & 8 & 1 & 4.11 & 8 \\
\hline & Highest education (respondent) $\mathrm{c}$ & 1 & 2.93 & 5 & 1 & 3.22 & 5 \\
\hline & Householder (respondent) race $\mathrm{c}$ & 1 & 1.55 & 7 & 1 & 1.33 & 7 \\
\hline & Respondent is Hispanic or Latino b & 0 & 0.19 & 1 & 0 & 0.10 & 1 \\
\hline & Respondent age a & 18 & 43.38 & 85 & 18 & 56.09 & 85 \\
\hline & Number of household members a & 1 & 2.51 & 10 & 1 & 2.61 & 12 \\
\hline & Number of household members below 18 a & 0 & 0.68 & 6 & 0 & 0.57 & 10 \\
\hline & Number of rooms, excluding bathrooms a & 1 & 4.40 & 18 & 1 & 6.95 & 19 \\
\hline & Number of full bathrooms a & 0 & 1.32 & 4 & 0 & 1.93 & 6 \\
\hline & Total square footage a & 221 & 1,218 & 5,487 & 228 & 2,448 & 8,501 \\
\hline & Type of housing unit $c$ & 1 & 3.72 & 5 & 1 & 2.12 & 5 \\
\hline & Range when housing unit was built $\mathrm{c}$ & 1 & 4.21 & 8 & 1 & 4.37 & 8 \\
\hline & Household moved in after $2009 \mathrm{~b}$ & 0 & 0.78 & 1 & 0 & 0.25 & 1 \\
\hline \multirow{16}{*}{$\begin{array}{l}\text { Appliance } \\
\text { quantity: } \\
\text { renters have } \\
\text { less }\end{array}$} & Air conditioning $(\mathrm{AC}) \mathrm{b}$ & 0 & 0.83 & 1 & 0 & 0.89 & 1 \\
\hline & $\mathrm{AC}$ is central b & 0 & 0.53 & 1 & 0 & 0.73 & 1 \\
\hline & More than one water heater $b$ & 0 & 0.01 & 1 & 0 & 0.05 & 1 \\
\hline & Number of light bulbs in home $c_{c}$ & 1 & 1.41 & 5 & 1 & 2.35 & 5 \\
\hline & Number of light bulbs outside home $\mathrm{c}$ & 0 & 0.45 & 3 & 0 & 1.46 & 3 \\
\hline & Number of refrigerators used a & 0 & 1.13 & 8 & 0 & 1.51 & 7 \\
\hline & Number of televisions a & 0 & 1.93 & 7 & 0 & 2.55 & 9 \\
\hline & Have clothes dryer in home using electricity $b$ & 0 & 0.48 & 1 & 0 & 0.75 & 1 \\
\hline & Number of ceiling fans a & 0 & 1.17 & 7 & 0 & 2.69 & 14 \\
\hline & Number of separate freezers used a & 0 & 0.15 & 3 & 0 & 0.47 & 4 \\
\hline & Electricity used for heating pool b & 0 & 0.00 & 1 & 0 & 0.01 & 1 \\
\hline & Hot tub using electricity $b$ & 0 & 0.01 & 1 & 0 & 0.05 & 1 \\
\hline & Have dishwasher b & 0 & 0.55 & 1 & 0 & 0.78 & 1 \\
\hline & Have clothes washer in home $b$ & 0 & 0.58 & 1 & 0 & 0.97 & 1 \\
\hline & Number of windows $\mathrm{c}$ & 10 & 27 & 60 & 10 & 39 & 60 \\
\hline & Internet access at home $\mathrm{b}$ & 0 & 0.80 & 1 & 0 & 0.88 & 1 \\
\hline Price & Electricity price $(\$ / \mathrm{kWh})_{\text {a }}$ & 0.03 & 0.14 & 1.07 & 0.00 & 0.14 & 0.37 \\
\hline \multirow{6}{*}{$\begin{array}{l}\text { Appliance } \\
\text { quantity: } \\
\text { renters have } \\
\text { more }\end{array}$} & Number individual air conditioning units a & 0 & 0.51 & 4 & 0 & 0.40 & 7 \\
\hline & Space heating (main fuel is electricity) b & 0 & 0.47 & 1 & 0 & 0.30 & 1 \\
\hline & Built-in electrical space heating $b$ & 0 & 0.16 & 1 & 0 & 0.04 & 1 \\
\hline & Portable electrical space heating $\mathrm{b}$ & 0 & 0.03 & 1 & 0 & 0.02 & 1 \\
\hline & Water heating (main fuel is electricity) b & 0 & 0.51 & 1 & 0 & 0.44 & 1 \\
\hline & Electrical cooking equipment $\mathrm{b}$ & 0 & 0.70 & 1 & 0 & 0.66 & 1 \\
\hline Efficiency/ & Age of central AC less than 5 years b & 0 & 0.15 & 1 & 0 & 0.18 & 1 \\
\hline Type & Age of individual AC less than 5 years b & 0 & 0.17 & 1 & 0 & 0.10 & 1 \\
\hline & Main electrical space heating less than 5 yrs b & 0 & 0.18 & 1 & 0 & 0.14 & 1 \\
\hline & Main electrical water heating less than 5 yrs b & 0 & 0.26 & 1 & 0 & 0.20 & 1 \\
\hline & Central AC is heat pump $\mathrm{b}$ & 0 & 0.14 & 1 & 0 & 0.21 & 1 \\
\hline & No incandescent light bulbs in home $b$ & 0 & 0.19 & 1 & 0 & 0.18 & 1 \\
\hline & TV type of LED or LCD $b$ & 0 & 0.66 & 1 & 0 & 0.76 & 1 \\
\hline & Most used television size is 60 inches plus b & 0 & 0.07 & 1 & 0 & 0.09 & 1 \\
\hline & Adequate level of insulation $b$ & 0 & 0.72 & 1 & 0 & 0.87 & 1 \\
\hline & Energy-star qualified lightbulbs b & 0 & 0.26 & 1 & 0 & 0.46 & 1 \\
\hline & Energy-star qualified windows b & 0 & 0.10 & 1 & 0 & 0.31 & 1 \\
\hline & Energy-star qualified water heating $\mathrm{b}$ & 0 & 0.14 & 1 & 0 & 0.39 & 1 \\
\hline & Energy-star qualified dishwasher b & 0 & 0.12 & 1 & 0 & 0.38 & 1 \\
\hline & Energy-star qualified clothes washer b & 0 & 0.20 & 1 & 0 & 0.49 & 1 \\
\hline & Energy-star qualified clothes dryer b & 0 & 0.18 & 1 & 0 & 0.44 & 1 \\
\hline & Energy-star qualified refrigerator b & 0 & 0.27 & 1 & 0 & 0.55 & 1 \\
\hline & Energy-star qualified freezer $b$ & 0 & 0.05 & 1 & 0 & 0.15 & 1 \\
\hline & On-site electricity generation from solar b & 0 & 0.00 & 1 & 0 & 0.02 & 1 \\
\hline & Smart thermostat b & 0 & 0.01 & 1 & 0 & 0.05 & 1 \\
\hline & Has electricity smart meter $\mathrm{b}$ & 0 & 0.16 & 1 & 0 & 0.26 & 1 \\
\hline Behaviour & Usually maintain central AC temperature $\mathrm{b}$ & 0 & 0.04 & 1 & 0 & 0.17 & 1 \\
\hline & Inside lights controlled by timers/dimmers b & 0 & 0.13 & 1 & 0 & 0.40 & 1 \\
\hline & Number of lights on at least 4 hours a day a & 0 & 5.26 & 45 & 0 & 8.22 & 80 \\
\hline & Most used TV on 4 plus hours a weekday b & 0 & 0.65 & 1 & 0 & 0.70 & 1 \\
\hline & Frequency of clothes dryer use per week a & 0 & 2.59 & 30 & 0 & 4.34 & 30 \\
\hline & Number of months pool used in prior year a & 0 & 0.04 & 8 & 0 & 0.49 & 12 \\
\hline & Number of months hot tub used in prior year a & 0 & 0.06 & 12 & 0 & 0.56 & 12 \\
\hline & Household has viewed smart meter data $\mathrm{b}$ & 0 & 0.03 & 1 & 0 & 0.04 & 1 \\
\hline & Number of weekdays someone is at home a & 0 & 3.09 & 5 & 0 & 3.54 & 5 \\
\hline Natural gas & No natural gas used in home $b$ & 0 & 0.44 & 1 & 0 & 0.41 & 1 \\
\hline Bill & Household pays for all electricity used $b$ & 0 & 0.85 & 1 & 0 & 0.98 & 1 \\
\hline payment & Household pays for all natural gas used $\mathrm{b}$ & 0 & 0.41 & 1 & 0 & 0.58 & 1 \\
\hline
\end{tabular}

Notes: The full sample size is 5,686. This includes 1,696 renters and 3,990 non-renters. Variables are identified as: numerical a, binary b, and categorical c. The regressions also control for residences which are "occupied without payment of rent", making the reference category "owned or being bought by someone in your household". 
Table A.2. Results, dependent variable: log annual electricity consumption (kilowatt hours).

\begin{tabular}{|c|c|c|c|c|c|}
\hline Explanatory variable & Coefficient & $\begin{array}{r}\text { Standard } \\
\text { error }\end{array}$ & $\begin{array}{l}\text { Explanatory variable } \\
\text { (continued) }\end{array}$ & $\begin{array}{l}\text { Coefficient } \\
\text { (continued) }\end{array}$ & $\begin{array}{r}\text { Standard } \\
\text { error } \\
\text { (cont. }) \\
\end{array}$ \\
\hline Renter, binary & 0.030 & $(0.020)$ & Number of windows: $3-5$ & $0.053 *$ & $(0.024)$ \\
\hline Socioeconomic variables & & & Number of windows: $6-9$ & $0.091 *$ & $(0.046)$ \\
\hline Income: $\$ 20,000-\$ 39,999$ & -0.025 & $(0.030)$ & Number of windows: $10-15$ & 0.097 & $(0.054)$ \\
\hline Income: $\$ 40,000-\$ 59,999$ & 0.006 & $(0.028)$ & Number of windows: $16-19$ & $0.105^{*}$ & $(0.054)$ \\
\hline Income: $\$ 60,000-\$ 79,999$ & 0.025 & $(0.037)$ & Number of windows: $20-29$ & $0.128 * *$ & $(0.053)$ \\
\hline Income: $\$ 80,000-\$ 99,999$ & 0.019 & $(0.052)$ & Number of windows: 30 plus & $0.161 * *$ & $(0.056)$ \\
\hline Income: $\$ 100,000-\$ 119,999$ & 0.033 & $(0.047)$ & Internet access at home & $0.085 * * *$ & $(0.017)$ \\
\hline Income: $\$ 120,000-\$ 139,999$ & $0.105 * *$ & $(0.042)$ & Electricity price & & \\
\hline Income: $\$ 140,000$ or more & $0.102 *$ & $(0.052)$ & Average electricity price, $\log$ & $-0.553 * *$ & $(0.230)$ \\
\hline Education: high school & -0.039 & $(0.024)$ & Appliance \# renters have more & & \\
\hline Education: some college & $-0.058 * *$ & $(0.024)$ & Number individual AC units & $0.037 * * *$ & $(0.009)$ \\
\hline Education: Bachelor degree & $-0.105 * * *$ & $(0.029)$ & Electrical space heating & $0.167 * * *$ & $(0.050)$ \\
\hline Education: postgraduate & $-0.084 * *$ & $(0.027)$ & Built-in space heating & $0.102 * * *$ & $(0.032)$ \\
\hline Race: African American & $0.082 * * *$ & $(0.009)$ & Portable space heating & 0.005 & $(0.040)$ \\
\hline Race: American Indian & -0.043 & $(0.072)$ & Electrical water heating & $0.115 * * *$ & $(0.028)$ \\
\hline Race: Asian & $-0.122 * *$ & $(0.040)$ & Cooking using electricity & $0.049 * *$ & $(0.020)$ \\
\hline Race: Hawaiian/Pacific & $0.157 * *$ & $(0.053)$ & Appliance efficiency/type & & \\
\hline Race: 2 or more races selected & 0.028 & $(0.031)$ & Age of central $\mathrm{AC}<5$ years & -0.008 & $(0.014)$ \\
\hline Hispanic or Latino & $-0.059 * *$ & $(0.025)$ & Age of individual $\mathrm{AC}<5 \mathrm{yrs}$ & -0.003 & $(0.022)$ \\
\hline Age & -0.001 & $(0.001)$ & Space heating $<5$ years & -0.020 & $(0.013)$ \\
\hline Number in household & $0.080 * * *$ & $(0.007)$ & Water heating $<5$ years & 0.015 & $(0.016)$ \\
\hline Number below 18 & $-0.030 * * *$ & $(0.009)$ & Central $\mathrm{AC}$ is heat pump & 0.006 & $(0.012)$ \\
\hline Number of rooms & 0.006 & $(0.004)$ & No incandescent light bulbs & -0.018 & $(0.012)$ \\
\hline Number full bathrooms & $0.049 * * *$ & $(0.012)$ & Television type & 0.002 & $(0.011)$ \\
\hline Total square footage, log & $0.065 * * *$ & $(0.011)$ & Big television & $0.068 * * *$ & $(0.011)$ \\
\hline Single-family detached house & -0.068 & $(0.048)$ & At least adequate insulation & -0.026 & $(0.017)$ \\
\hline Single-family attached house & $-0.180 * * *$ & $(0.050)$ & Energy-star lightbulbs & $-0.022 * *$ & $(0.008)$ \\
\hline Apartment in 2-4 unit block & $-0.279 * * *$ & $(0.082)$ & Energy-star windows & $-0.044 * *$ & $(0.015)$ \\
\hline Apartment in $5+$ unit block & $-0.349 * * *$ & $(0.096)$ & Energy-star water heating & 0.005 & $(0.015)$ \\
\hline House made: 1990-1999 & $-0.051 * *$ & $(0.020)$ & Energy-star dishwasher & 0.030 & $(0.019)$ \\
\hline House made: $2000-2009$ & $-0.048 * *$ & $(0.020)$ & Energy-star clothes washer & -0.007 & $(0.024)$ \\
\hline House made: $2010-2015$ & $-0.095 * *$ & $(0.035)$ & Energy-star clothes dryer & 0.040 & $(0.024)$ \\
\hline Moved in after 2009 & $-0.094 * * *$ & $(0.014)$ & Energy-star refrigerator & -0.017 & $(0.013)$ \\
\hline Appliance \#: renters have less & & & Energy-star freezer & $-0.049 * *$ & $(0.020)$ \\
\hline Air conditioning & $0.123 * *$ & $(0.045)$ & Solar & -0.069 & $(0.081)$ \\
\hline $\mathrm{AC}$ is central & $0.097 * * *$ & $(0.029)$ & Smart thermostat & -0.020 & $(0.025)$ \\
\hline More than one water heater & $0.098 * * *$ & $(0.026)$ & Smart meter & 0.026 & $(0.020)$ \\
\hline Number of lightbulbs: 20-39 & 0.001 & $(0.019)$ & Behaviour & & \\
\hline Number of lightbulbs: 40-59 & -0.027 & $(0.027)$ & Maintain central AC temp. & $0.041 * *$ & $(0.015)$ \\
\hline Number of lightbulbs: 60-79 & -0.039 & $(0.028)$ & Light timers & $0.022 *$ & $(0.011)$ \\
\hline Number of lightbulbs: $80+$ & 0.036 & $(0.036)$ & \# lights on $4+$ hours a day & $0.005 * * *$ & $(0.001)$ \\
\hline Outside lightbulbs: $1-4$ & -0.042 & $(0.048)$ & TV on $4+$ hours a weekday & $0.049 * *$ & $(0.021)$ \\
\hline Outside lightbulbs: 5-9 & -0.012 & $(0.053)$ & Dryer use per week (\#) & $0.013 * * *$ & $(0.003)$ \\
\hline Outside lightbulbs: 10 plus & 0.026 & $(0.042)$ & Pool use (months a year) & 0.002 & $(0.013)$ \\
\hline Number of refrigerators used & $0.072 * * *$ & $(0.009)$ & Hot-tub use (months a year) & $0.024 * * *$ & $(0.007)$ \\
\hline Number of televisions used & $0.029 * * *$ & $(0.007)$ & Viewed smart meter & -0.026 & $(0.030)$ \\
\hline Have clothes dryer in home & -0.007 & $(0.030)$ & Weekdays at home (\#) & 0.005 & $(0.004)$ \\
\hline Number of ceiling fans & 0.008 & $(0.006)$ & Binary natural gas variable & & \\
\hline Number of separate freezers & $0.099 * * *$ & $(0.014)$ & No natural gas used in home & $0.156 * * *$ & $(0.041)$ \\
\hline Electricity-heated swim pool & $0.271 * * *$ & $(0.082)$ & Bill payment responsibility & & \\
\hline Hot tub using electricity & -0.058 & $(0.064)$ & Pays full electricity bill & -0.082 & $(0.057)$ \\
\hline Have dishwasher & $0.062 * * *$ & $(0.008)$ & Pays full natural gas bill & 0.047 & $(0.029)$ \\
\hline Have clothes washer in home & $0.092 * * *$ & $(0.025)$ & & & \\
\hline
\end{tabular}

Notes. $* * *, * * *$ show statistical significance at 1, 5 and 10 per cent level respectively. The omitted reference groups are: annual household income below $\$ 20,000$, highest education below high school diploma, householder race of white, mobile home, house made before 1950, number of inside light bulbs less than 20, zero outside lightbulbs, and number of windows less than 3. Insignificant coefficients for houses made from 1950-1989 are not shown. There are 5,066 observations. The $R_{2}$ is 0.667 . Coefficients are not shown for the constant, region fixed effects (metropolitan/micropolitan/neither status, climate zone, and natural gas in neighbourhood status). Education, race, and age refer to the respondent rather than the entire household. Education is the highest education. The regressions also control for residences which are "occupied without payment of rent", making the reference category "owned or being bought by someone in your household". 